\title{
PHYTOCHEMICAL STUDIES AND GAS CHROMATOGRAPHY-MASS SPECTROMETRY ANALYSIS OF SARCOSTEMMA BREVISTIGMA, WIGHT \& ARN.
}

\author{
DHIVYA SM*, KALAICHELVI K \\ Department of Botany, Vellalar College for Women (Autonomous), Thindal, Erode, Tamil Nadu, India. Email: diviproject27a8@gmail.com \\ Received: 09 December 2016, Revised and Accepted: 28 December 2016
}

\begin{abstract}
Objective: To explore the phytochemical constituents present in Sarcostemma brevistigma using gas chromatography-mass spectrometry (GC-MS).

Methods: Preliminary phytochemical analysis of secondary metabolites was made by following standard procedures. GC-MS analysis of the plant extracts was performed by using GC-MS equipped with a DB-35MS capillary standard non-polar column and gas chromatograph interfaced to a Mass Selective Detector (MS-DSQ-II) with Xcalibur software.
\end{abstract}

Results: The qualitative phytochemical analysis of this species exhibited the presence of alkaloids, glycosides, flavonoids, phenols, steroids, amino acids, tannins, terpenoids, quinones, and coumarin. The GC-MS analysis revealed the presence of 24 compounds in the ethanolic extract of aerial part of Sarcostemma brevistigma. The most prevailing compound was 14,17 bis(dimethylaminoamino)[3.3]paracyclophan-5,8-diacetonitrile (14.86\%).

Conclusion: The study concludes that the species Sarcostemma brevistigma is a potential source for bioactive compounds such as esters, alkanes, alcohols, alkenes, amide, amine, phenol, ketone, and so forth. This study justifies the traditional usage of this species.

Keywords: Gas chromatography-mass spectrometry, Sarcostemma brevistigma, Phytochemical compounds, Medicinal plants.

(C) 2017 The Authors. Published by Innovare Academic Sciences Pvt Ltd. This is an open access article under the CC BY license (http://creativecommons. org/licenses/by/4. 0/) DOI: http://dx.doi.org/10.22159/ajpcr.2017.v10i3.16538

\section{INTRODUCTION}

For millennia, people around the world have healed the sick with herbal derived remedies and handed down through generations. Traditional medicine is the sum total of knowledge, skills and practices based on the theories, beliefs and experiences indigenous to different cultures that are used to maintain health, as well as to prevent, diagnose, improve or treat physical and mental illness [1]. Various types of traditional medicine and other medical practices referred to as complementary or alternative medicine are increasingly used in both developing and developed countries.

Presently, there is an increasing interest worldwide in herbal medicines accompanied by increased laboratory investigations into the pharmacological properties of the bioactive ingredients and their ability to treat various diseases. Various drugs have entered into the international market through exploration of ethnopharmacology and traditional medicine. Although scientific studies are carried out on a large number of plants, smaller number of marketable drugs or phytochemical entities has entered the evidence-based therapeutics [2]. Even today, bioactive compounds from plants continue to play a major role in health-care benefits [3]. GC for bioactive components is the more appropriate technique to identify the new phytochemicals of medicinal importance which have higher activity against many diseases [4,5].

Sarcostemma brevistigma, Wight \& Arn. is a potential medicinal plant belonging to the family Asclepiadaceae. It is used in the traditional systems of medicine for various ailments. The decoction of the plant is useful to gargle for throat and mouth infection. Fresh roots are prescribed for jaundice [6,7]. The plant is hot, bitter, tonic, expectorant, pungent, dry and indigestible causes flatulence, diuretic, laxative, aphrodisiac, anthelmintic, useful in leukoderma and bronchitis. The juice is used in gleet, gonorrhea, pain in the muscles, cough and given to children as an astringent [8]. Leaf powder stimulates articulatory system, increases secretion of urine and activates uterus [9]. The fruit juice is used in gonorrhea and to relieve pain in muscles [10]. The leaves, roots, and latex are employed in treating asthma, rheumatism, arthritis, chronic ulcer, fever, cough, snake bite, bronchitis, dysentery, purgative, leprosy, tumor, vesicant, constipation, skin diseases, and stomach distension [11] in Tamil Nadu, India. However, no much scientific validation has been made for this species for its medicinal uses.

To address the lacuna, this study was aimed to evaluate the phytochemical compounds present in the ethanolic extract of aerial part of Sarcostemma brevistigma using gas chromatography-mass spectrometry (GC-MS) analysis.

\section{METHODS}

Chemicals

In this study, all the chemicals were purchased from Hi Media Pvt. Ltd., Mumbai. The chemicals used were of analytical grade.

\section{Collection and identification of plant material}

Sarcostemma brevistigma was collected from Pillur Beat (Pillur slope RF and Nellithurai RF), Karamadai Range, Western Ghats, Tamil Nadu, India. The authenticity of the plant was confirmed in Botanical Survey of India, Southern Circle, Coimbatore by referring the deposited specimen. The voucher number of the specimen was BSI/SRC/5/23/2015/ Tech./2334.

\section{Preparation of extract}

The aerial parts were washed under running tap water, shade dried at room temperature, and powdered. The powdered plant sample $(50 \mathrm{~g} / 250 \mathrm{ml})$ was extracted successively with ethanol, methanol, hexane and water using Soxhlet apparatus at $55-850^{\circ} \mathrm{C}$ for $8-10 \mathrm{hrs}$ to extract the polar and non-polar compounds [12]. For each solvent extraction, the powdered pack material was air dried and then used. The solvents of the respective extracts were reduced under room 
temperature and stored at $4{ }^{\circ} \mathrm{C}$ for further use. The dried plant extracts were then redissolved in dimethyl sulfoxide to get the solution of $10 \mathrm{mg} / 10 \mathrm{ml}$ for each extract which was subjected to analysis of phytochemicals and GC-MS studies.

\section{Phytochemical screening}

Preliminary qualitative phytochemical analysis was carried out to identify the secondary metabolites present in ethanol, methanol, hexane, and aqueous extract of aerial part of test plant.

\section{GC-MS analysis}

Ethanolic extract of aerial part of Sarcostemma brevistigma was analyzed for the presence of different volatile compounds by GC-MS technique. GC-MS analysis of some of the potent volatile constituents present in the extract was performed at the South India Textile Research Association, Coimbatore, Tamil Nadu, India. GC analysis of the extracts was performed using a GC-MS (Model; Thermo Trace GC Ultra Ver. 5.0, Thermo MS DSQ II) equipped with a DB-35MS capillary standard non-polar column (30 m length $\times$ outside diameter $0.25 \mathrm{~mm} \times$ internal diameter $0.25 \mu \mathrm{m}$ ) and gas chromatograph interfaced to a Mass Selective Detector (MSDSQ-II) with Xcalibur software. For GC-MS detection, an electron ionization system with ionization energy of $-70 \mathrm{eV}$ was used. Helium gas was used as a carrier gas at a constant flow rate of $1 \mathrm{ml} /$ minutes and the sample injected was $1 \mu \mathrm{l}$; Injector temperature $260^{\circ} \mathrm{C}$; Ion source temperature $200^{\circ} \mathrm{C}$. The oven temperature was programmed from $75^{\circ}$ to $260^{\circ} \mathrm{C}$ at the rate of $10^{\circ} \mathrm{C} /$ minutes, held isothermal for 1 minute and finally raised to $260^{\circ} \mathrm{C}$ at $6^{\circ} \mathrm{C} /$ minutes. Interface temperature was kept at $260^{\circ} \mathrm{C}$. Total GC run time was 37.53 minutes. The relative percentage of each extract constituent was expressed as a percentage with peak area normalization.

\section{Identification of bioactive compounds}

The identification of the components in the extract was assigned by the comparison of their retention indices and mass spectra fragmentation patterns with those stored on the computer library and also with published literatures. NIST (Mc Lafferly, 1989), WILEY (Stein, 1990) library sources were also used for matching the identified components from the plant material.

\section{RESULTS}

The preliminary phytochemical screening of Sarcostemma brevistigma revealed the presence of alkaloids, glycosides, flavonoids, phenols, saponins, steroids, amino acids, tannins, terpenoids, quinones, anthraquinones, and coumarin (Table 1).

The total ion chromatogram of ethanol extract of Sarcostemma brevistigma showing the GC-MS profile of the compounds identified was given in Fig. 1. The peaks in the chromatogram were integrated and were compared with the database of the spectrum of known components stored in the GC-MS library. The detailed tabulation of GCMS analysis was given in Table 2 .

A total of 24 compounds were identified in the ethanolic extract of the plant. The identification of phytochemical compounds was based on the peak area, retention time, molecular weight, and molecular formula. The highest peak area (\%) of 14.86 was obtained by 14,17 bis(dimethylamino amino)[3,3] paracyclophan-5,8-diacetonitrile (cyanide) with retention time 34.66 and the lowest peak area (\%) of 1.73 was obtained by 0,0-dipropyl isopropylphosphonate (phenol) with retention time 32.32 .

\section{DISCUSSION}

The phytochemical analysis revealed the presence of alkaloids, glycosides, flavonoids, phenols, saponins, steroids, tannins, terpenoids, anthraquinones, quinones, starch, gum, amino acid, coumarin, and fixed oil (Table 1). These phytochemicals exhibited a wide range of biological effects as consequence of their antioxidant properties $[13,14]$

The bioactive compounds phenols, flavonoids, alkaloids, tannins, and many other compounds have been reported to be free radical scavengers and inhibitors of lipid peroxidation [15], and these compounds show important properties such as anticancer, hepatoprotective effect, antioxidant, antiglycemic, anti-inflammatory, wound healing, analgesic, and many more $[16,17]$. The antioxidant properties of phenolic acids and flavonoids were due to their redox properties, ability to chelate metals, and quenching of singlet oxygen [18].

Alkaloids have been associated with medicinal uses for centuries, and one of their common biological properties was their cytotoxicity [19],

Table 1: Qualitative phytochemical screening of the plant extracts of Sarcostemma brevistigma

\begin{tabular}{llllll}
\hline \multirow{2}{*}{ S. No. } & Phyto & \multicolumn{4}{l}{ Aerial parts of Sarcostemma brevistigma } \\
\cline { 3 - 6 } & constituents & Hexane & Ethanol & Methanol & Aqueous \\
\hline 1. & Alkaloids & In traces & ++ & ++ & In traces \\
2. & Flavonoids & ++ & +++ & +++ & ++ \\
3. & Quinones & In traces & ++ & In traces & In traces \\
4. & Phenols & ++ & ++ & ++ & ++ \\
5. & Tannins & ++ & ++ & ++ & ++ \\
6. & Saponins & - & + & - & - \\
7. & Steroids & + & ++ & ++ & + \\
8. & Antraquinones & + & + & + & + \\
9. & Terpenoids & ++ & ++ & ++ & + \\
10. & Coumarin & + & + & + & ++ \\
11. & Glycosides & +++ & +++ & +++ & +++ \\
\hline
\end{tabular}

$(+++)$ : Highly present, $(++)$ : Moderately present, $(+)$ : Low Present, $(-)$ : Absent

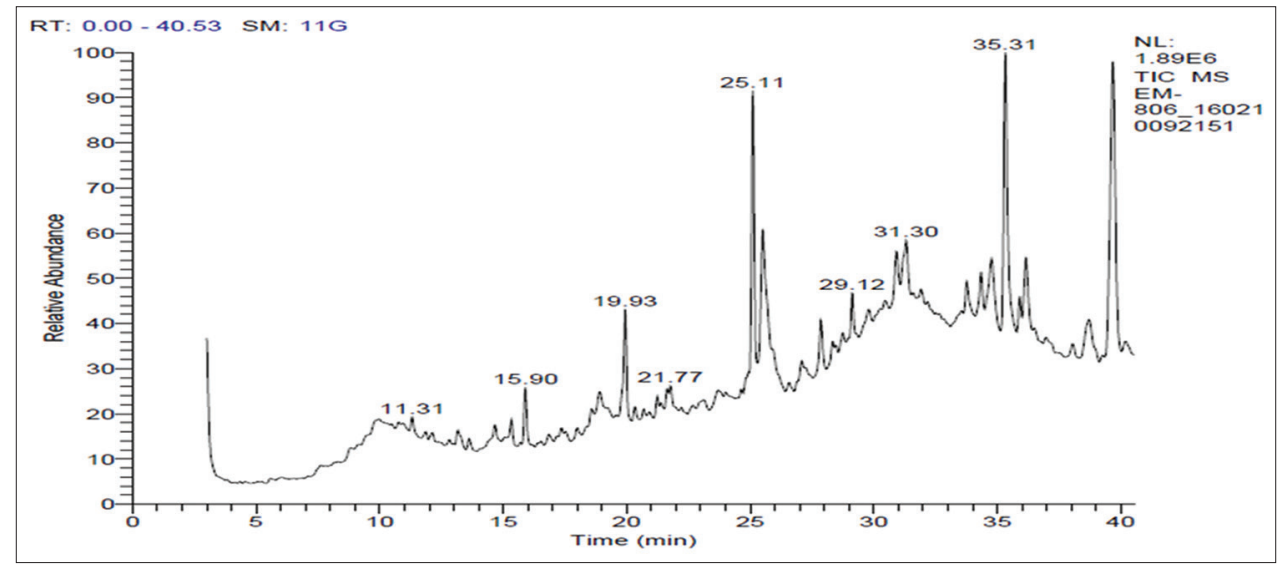

Fig. 1: Gas chromatography-mass spectrometry chromatogram of ethanolic extract of Sarcostemma brevistigma 
Table 2: Bioactive compounds identified in the ethanolic extract of Sarcostemma brevistigma

\begin{tabular}{|c|c|c|c|c|c|c|c|}
\hline S. No. & RT & Compound name & $\begin{array}{l}\text { Molecular } \\
\text { formula }\end{array}$ & $\begin{array}{l}\text { Molecular } \\
\text { weight }\end{array}$ & $\begin{array}{l}\text { Area } \\
\%\end{array}$ & $\begin{array}{l}\text { Functional } \\
\text { groups }\end{array}$ & Biological activities \\
\hline 1. & 9.95 & 3,4 [methylenedioxy] phenethylamine & $\mathrm{C}_{9} \mathrm{H}_{11} \mathrm{NO}_{2}$ & 165 & 1.33 & Amine & $\begin{array}{l}\text { Analgesics that are } \\
\text { pain killers, increase } \\
\text { brain function, } \\
\text { disinfection of } \\
\text { drinking water }\end{array}$ \\
\hline 2. & 17.32 & 9-chloro-9-methoxy-9H-fluorene & $\mathrm{C}_{14} \mathrm{H}_{11} \mathrm{C}_{10}$ & 230 & 1.53 & Methyl ester & $\begin{array}{l}\text { Antiinflammation and } \\
\text { antimicrobial activity }\end{array}$ \\
\hline 3. & 20.89 & Butyl glycol acetate & $\mathrm{C}_{8} \mathrm{H}_{16} \mathrm{O}_{3}$ & 160 & 2.58 & Ester & $\begin{array}{l}\text { Antioxidant, flavour, } \\
\text { hypocholesterolemic, } \\
\text { nematicide, } \\
\text { pesticide, lubricant, } \\
\text { antiandrogenic, } \\
\text { haemolytic, 5-alpha } \\
\text { reductase inhibitor }\end{array}$ \\
\hline 5. & 26.37 & $\begin{array}{l}\text { Methyl 2-diazo-3-oxo-4-propylhept- } \\
\text { 6-enoate }\end{array}$ & $\mathrm{C}_{11} \mathrm{H}_{16} \mathrm{~N}_{2} \mathrm{O}_{3}$ & 224 & 1.08 & Ester & $\begin{array}{l}\text { Antioxidant, flavour, } \\
\text { hypocholesterolemic, } \\
\text { nematicide, } \\
\text { pesticide, lubricant, } \\
\text { antiandrogenic, } \\
\text { haemolytic, } 5 \text {-alpha } \\
\text { reductase inhibitor }\end{array}$ \\
\hline 6. & 27.02 & $\begin{array}{l}\text { 1-(dimethylamino)-4,5-dihydro } \\
\text {-3-methyl-1H-benz[g] indole }\end{array}$ & $\mathrm{C}_{15} \mathrm{H}_{18} \mathrm{~N}_{2}$ & 226 & 1.12 & Amine & $\begin{array}{l}\text { Analgesics that are } \\
\text { pain killers, increase } \\
\text { brain function, } \\
\text { disinfection of } \\
\text { drinking water }\end{array}$ \\
\hline 7. & 29.24 & $\begin{array}{l}\text { Cyclohexane, 1,3,5-trimethyl } \\
\text {-2-octadecyl- (CAS) }\end{array}$ & $\mathrm{C}_{27} \mathrm{H}_{54}$ & 378 & 4.50 & Alkane & $\begin{array}{l}\text { Antimicrobial } \\
\text { agents, trans ducer } \\
\text { for immunosensor } \\
\text { and its method } \\
\text { of production, } \\
\text { carcinogens, enzymes } \\
\text { inhibitors }\end{array}$ \\
\hline 8. & 30.04 & $\begin{array}{l}\text { 6-Methyl-14H-benzo[6,7]cyclohepta[1,2-b] } \\
\text { naphtha }[1,2-d] \text { indole-14-one }\end{array}$ & $\mathrm{C}_{22} \mathrm{H}_{15} \mathrm{NO}$ & 309 & 1.22 & Ketone & $\begin{array}{l}\text { Dry asthma, colds, flu } \\
\text { and dry cough }\end{array}$ \\
\hline 9. & 30.53 & 7-Hydroxycymopochromenol & $\mathrm{C}_{16} \mathrm{H}_{21} \mathrm{BrO}_{3}$ & 340 & 1.89 & Hydroxyl & Antimicrobial activity \\
\hline 10. & 31.26 & Cis-2,3-epoxy-1-cyclohexanol & $\mathrm{C}_{6}^{16} \mathrm{H}_{10}^{21} \mathrm{O}_{2}$ & 114 & 2.28 & $\begin{array}{l}\text { Alcoholic } \\
\text { compound }\end{array}$ & Antimicrobial activity \\
\hline 11. & 31.85 & $\begin{array}{l}\text { 7-hydroxymethyl-1-bromo } \\
\text {-4-isopropoxy-5-methoxy naphthalene }\end{array}$ & $\mathrm{C}_{15} \mathrm{H}_{17} \mathrm{BrO}_{3}$ & 324 & 4.64 & $\begin{array}{l}\text { Aromatic } \\
\text { bicyclic } \\
\text { compound }\end{array}$ & $\begin{array}{l}\text { Anticancerous } \\
\text { activity }\end{array}$ \\
\hline 12. & 32.32 & 0, 0-dipropyl isopropylphosphonate & $\mathrm{C}_{9} \mathrm{H}_{21} \mathrm{O}_{3} \mathrm{P}$ & 208 & 1.73 & Phenol & $\begin{array}{l}\text { Antioxidant, } \\
\text { analgesics antipyretic } \\
\text { and antiinflammatory }\end{array}$ \\
\hline 13. & 32.87 & $\begin{array}{l}\text { Tricarbonyl [ü(4)-diethyl } \\
\text {-2,5-dihydro-2,3-dimethyl-ex o } \\
\text {-2-phenyl-1H-1,2,5 azasilaborol] iron }\end{array}$ & $\mathrm{C}_{17} \mathrm{H}_{22} \mathrm{BFeNO}_{3} \mathrm{Si}$ & 383 & 2.87 & Phenol & $\begin{array}{l}\text { Antioxidant, } \\
\text { analgesics, antipyretic } \\
\text { and antiinflammatory }\end{array}$ \\
\hline 14. & 33.32 & $\begin{array}{l}\text { Methyl-2,3,4-Tris-0-[9 borabicyclo[3.3.1] } \\
\text { Non-9-Yl]-À-D-Xylopyranoside }\end{array}$ & $\mathrm{C}_{30} \mathrm{H}_{51} \mathrm{~B}_{3} \mathrm{O}_{5}$ & 524 & 2.47 & $\begin{array}{l}\text { Heterocyclic } \\
\text { compound }\end{array}$ & $\begin{array}{l}\text { Antiinflammatory, } \\
\text { anti-HIV, } \\
\text { anticancerous, } \\
\text { antifungal and } \\
\text { antiviral activity }\end{array}$ \\
\hline 15. & 33.68 & $\begin{array}{l}\text { 2',3',5,6,6'7'-hexamethylspiro } \\
\text { [benzofuran-3 (2H)-9'-[9 H]-xanthen-2-one }\end{array}$ & $\mathrm{C}_{26} \mathrm{H}_{24} \mathrm{O}_{3}$ & 384 & 5.49 & Ketone & $\begin{array}{l}\text { Dry asthma, colds, flu } \\
\text { and dry cough }\end{array}$ \\
\hline 16. & 33.97 & $\begin{array}{l}3,4 \text { bis }(3,4,5 \text {-trimethoxyphenyl }) \\
\text {-1-[2-(4-methoxyphenyl) ethyl] } \\
\text { pyrrole-2,5-dicarboxylic acid }\end{array}$ & $\mathrm{C}_{33} \mathrm{H}_{35} \mathrm{NO}_{11}$ & 621 & 2.90 & $\begin{array}{l}\text { Carboxylic } \\
\text { compound }\end{array}$ & Joint pain and fever \\
\hline 17. & 34.66 & $\begin{array}{l}14,17 \text { bis (dimethylaminoamino) [3.3] } \\
\text { paracyclophan-5,8-diacetonitrile }\end{array}$ & $\mathrm{C}_{26} \mathrm{H}_{32} \mathrm{~N}_{4}$ & 400 & 14.86 & Cyanide & $\begin{array}{l}\text { Tuberculosis and } \\
\text { leprosy }\end{array}$ \\
\hline
\end{tabular}


Table 2: (Continued)

\begin{tabular}{|c|c|c|c|c|c|c|c|}
\hline S. No. & RT & Compound name & $\begin{array}{l}\text { Molecular } \\
\text { formula }\end{array}$ & $\begin{array}{l}\text { Molecular } \\
\text { weight }\end{array}$ & $\begin{array}{l}\text { Area } \\
\%\end{array}$ & $\begin{array}{l}\text { Functional } \\
\text { groups }\end{array}$ & Biological activities \\
\hline 18. & 35.11 & $\begin{array}{l}\text { 6á-Acetylamido-5à } \\
\text {-hydroxyandrostane-3á,7á-diiacetate }\end{array}$ & $\mathrm{C}_{25} \mathrm{H}_{39} \mathrm{NO}_{6}$ & 449 & 1.31 & Ester & $\begin{array}{l}\text { Antioxidant, flavour, } \\
\text { hypocholesterolemic, } \\
\text { nematicide, } \\
\text { pesticide, lubricant, } \\
\text { antiandrogenic, } \\
\text { haemolytic, 5-alpha } \\
\text { reductase inhibitor }\end{array}$ \\
\hline 19. & 35.60 & $\begin{array}{l}\text { 1-(3-chloro-phenyl)-5-[(2-mercapto-phe } \\
\text { nylamino)-methylene]-2-thioxo-dihyd } \\
\text { ro-pyrimidine-4,6-dione }\end{array}$ & $\mathrm{C}_{17} \mathrm{H}_{12} \mathrm{ClN}_{3} \mathrm{O}_{2} \mathrm{~S}_{2}$ & 389 & 7.66 & Diketone & $\begin{array}{l}\text { Antiulcer, and } \\
\text { gastroprotective } \\
\text { drugs, antiasthmatics } \\
\text { and lung diseases, } \\
\text { carcinogenic agents, } \\
\text { antidiabetic agents }\end{array}$ \\
\hline 20. & 36.23 & $\begin{array}{l}\text { Butanesulfonic acid, 4- } \\
\text { (diphenylphosphinyl)-, methyl ester }\end{array}$ & $\mathrm{C}_{17} \mathrm{H}_{21} \mathrm{O}_{4} \mathrm{PS}$ & 352 & 3.15 & Methyl ester & $\begin{array}{l}\text { Antiinflammation and } \\
\text { antimicrobial activity }\end{array}$ \\
\hline 21. & 37.49 & $\begin{array}{l}12 \text {-Hydroxy-9-methyl-5H,11H } \\
\text {-pyrano[3',2':6,7][1]benzopyrano[3,4-c] } \\
\text { pyridine-5,11-dione } \\
\text { (Isoschumanniophytine) }\end{array}$ & $\mathrm{C}_{16} \mathrm{H}_{9} \mathrm{NO}_{5}$ & 295 & 5.01 & Diketone & $\begin{array}{l}\text { Antiulcer, and } \\
\text { gastroprotective } \\
\text { drugs, antiasthmatics } \\
\text { and lung diseases, } \\
\text { carcinogenic agents, } \\
\text { antidiabetic agents }\end{array}$ \\
\hline 22. & 37.76 & $\begin{array}{l}\text { 1-(ethoxycarbonyl)-5-chloro } \\
\text {-4-methoxy-3-ethylpent an-2-one }\end{array}$ & $\mathrm{C}_{11} \mathrm{H}_{19} \mathrm{CIO}_{4}$ & 250 & 2.51 & Ketone & $\begin{array}{l}\text { Dry asthma, colds, flu } \\
\text { and dry cough }\end{array}$ \\
\hline 23. & 38.70 & $\mathrm{~N}$-fluoresceinylpropanamide & $\mathrm{C}_{23} \mathrm{H}_{15} \mathrm{NO}_{6}$ & 401 & 1.74 & Amide & Anesthetic agents \\
\hline 24. & 39.39 & $\begin{array}{l}\text { 2,9-bis[(diethoxyphosphinyl) } \\
\text { methyl]-1,10-phenanthroline }\end{array}$ & $\mathrm{C}_{22}^{23} \mathrm{H}_{30} \mathrm{~N}_{2} \mathrm{O}_{6} \mathrm{P}_{2}$ & 480 & 1.68 & Amine & $\begin{array}{l}\text { Analgesics that are } \\
\text { pain killers, increase } \\
\text { brain function, } \\
\text { disinfection of } \\
\text { drinking water }\end{array}$ \\
\hline
\end{tabular}

used as central nervous system stimulant, topical anesthetic in ophthalmology, powerful pain reliever [20], antipyretic, antispasmodic, and antibacterial [21]. Cardiac glycosides were known to lower the blood pressure according to many reports [22].

In general, the reliability of medicinal plant for its usage was evaluated by correlating the phytochemical compounds with their biological activities [23]. GC-MS analysis of plant extract showed the presence of 24 compounds (Table 2 and Fig. 1). Out of these, various compounds have got their applications in pharmaceutical industries. The methyl ester in the plant extract had anti-inflammatory, antiandrogenic, antioxidant, hypercholesterolemic and antimicrobial activities [24-26] and the esters have been reported to have antioxidant, hypocholesterolemic, nematicide, pesticide, lubricant, antiandrogenic, hemolytic, 5-alpha reductase inhibitor activities. Alkanes were antimicrobial agents, transducer for immunosensor and anticarcinogens [27]. Ketone could act on dry asthma, colds, flu, and dry cough. Phenol was an antioxidant and showed analgesics, antipyretic and anti-inflammatory properties. As GC-MS was the first step toward understanding the nature of active principles $[28,29]$, further investigation in this species was suggested for the development of novel drugs.

As per our knowledge, this is the first study on the identification of important phytoconstituents in ethanolic extract of Sarcostemma brevistigma aerial parts. Plant extract has shown the presence of various compounds of pharmaceutical and industrial importance. Therefore, aerial parts could be used for the sourcing of these compounds from the extract prepared through the method described herein.

\section{CONCLUSION}

The results obtained in this study thus suggested that the aerial part of Sarcostemma brevistigma was an increasingly valuable reservoir of potential bioactive compounds with socioeconomic importance. This study also helps to predict the formula and structure of biomolecules which can be used as drugs. Further investigation may lead to the development of drug formulation.

\section{ACKNOWLEDGMENT}

The authors are highly thankful to the Ranger and Guard who have provided the valuable information and accompanied us during field collection of the study plant in Pillur Beat. We are also thankful to South India Textile Research Association (SITRA) for helping us with our experiments.

\section{REFERENCES}

1. Home Page on the Internet, World Health Organization. Available from: http://www.who.int/medicines/areas/traditional/definitions/en/.

2. Nakahara K, Roy MK, Alzoreky NS, Thalang V, Trakoontivakorn G. Inventory of Indigenous Plants and Minor Crops in Thailand Based on Bioactivities: $9^{\text {th }}$ JIRCAS. International Symposium-Value Addition to Agricultural Product; 2001. p. 135-9.

3. Karuppasamy B, Antony N, Veerabahu RM. GC-MS analysis of Polycarpaea corymbosa (L.) Lam. whole plant. Asian Pac J Trop Biomed 2012;2(3):1289-92.

4. Gopalakrishnan S. GC-MS analysis of some bioactive constituents of Mussaenda frondosa Linn. Int J Pharm Biosci 2011;2(1):313-20.

5. Janakiraman N, Johnson M, Sathish SS. GC-MS analysis of bioactive constituents of Peristrophe bicalyculata (Rets.) Nees. (Acanthaceae). Asian Pac J Trop Biomed 2012;46-9.

6. Chopra RN, Chopra IC, Handa KL, Kapoor LD. Indigenous Drugs of India. Calcutta, India: Academic Publishers; 1958.

7. Nadkarni AK. Indian Material Medica, Popular. Mumbai: Prakashan Pvt., Ltd.; 1982.

8. Poornima N, Umarrajan KM, Babu K. Studies on anatomical and phytochemical analysis of Oxystelma esculentum (L.f) R. Br. Ex Schltes. Int J Bot Res 2009;2(4):239-43.

9. Prajapati ND, Purohit SS, Sharma AK, Kumar TA. Hand Book of Medicinal Plants. India: Agrobios; 2003.

10. Kirtikar KR, Basu BD. Indian Medicinal Plants. Dehradun, India: International Book Distributors; 1976. 
11. Dahiya K, Verma M, Dhankhar R, Singh V, Ghalaut PS, Seth S. Alteration of ischemia modified albumin and nitric oxide levels in hypothyroidism. Clin Lab 2014;60(6):969-72.

12. Elgorashi EE, Van Staden J. Pharmacological screening of six Amaryllidaceae species. J Ethnopharmacol 2004;90(1):27-32.

13. Vishnu R, Nisha R, Jamuna S, Paulsamy S. Quantification of total phenolics and flavonoids and evaluation of in vitro antioxidant properties of methanolic leaf extract of Tarenna asiatica - An endemic medicinal plant species of Maruthamali hills. Western Ghats, Tami Nadu. J Res Plant Sci 2013;2(2):196-204.

14. Benedec D, Vlase L, Oniga I, Mot AC, Damian G, Hanganu D, et al. Polyphenolic composition, antioxidant and antibacterial activities for two Romanian subspecies of Achillea distans Waldst. et Kit. ex Wild. Molecules 2013;18(8):8725-39.

15. Gbadamosi IT, Moody JO, Lawal AM. Phytochemical screening and proximate analysis of eight ethno botanicals used as antimalaria remedies in Ibadan, Nigeria. J Appl Biosci 2011;44:2967-71.

16. Bisht R, Chanyal S, Agrawal PK. Antimicrobial and phytochemical analysis of leaf extract of medicinal fruit plants. Asian J Pharm Clinical Res 2016;9(4):131-6.

17. Porwal V, Singh P, Gurjar DA. Comprehensive study on different methods of extraction from Guajava leaves for curing various health problems. Int J Eng Res 2012;2(6):490-6.

18. Sathyaprabha G, Kumaravel S, Ruffina D, Praveenkumar PA. Comparative study on antioxidant, proximate analysis, antimicrobial activity and phytochemical analysis of Aloe and Cissus quadrangularis by GC-MS. J Pharm Res 2010;3:2970-3.

19. Ngane AN, Biyiti L, Bouchet PH, Nkegfact A, Zolo PH. Antifungal activity of Piper guineense of Cameroun. Fitoterapia 2003;4(5):464-8.

20. Nwinyi OC, Chinedu NS, Ajani OO. Evaluation of antibacterial activity of Pisidium guajava and Gongronema latifolium. J Med Plants Res 2008;2(8):189-92

21. Nwaichi EO, Igbinobara O. Effect of some selected spices on some biochemical profile of wistar Albino rats. Am J Environ Engine 2012;2(1):8-11.

22. Kumar A, Rani S, Niketa SS. Recent review on plant molecular biology, phytophysiology, phytochemistry and ethnopharmacology of Cuscuta reflexa Roxb. A wonderful parasitic plant. Int Res J Pharm 2012;3(7):30-8

23. Belkacem N, Djaziri R, Lahfa F, El-Haci IA, Boucherit Z. Phytochemical screening and in vitro antioxidant activity isolated bioactive compounds from Tridax procumbens Linn. Paki J Biol Sci 2013;16(24):1971-7.

24. Jegadeeswari $P$, Nishanthini A, Muthukumarasamy S, Mohan VR. GC-MS analysis of bioactive components of Aristolochia krysagathra (Aristolochiaceae). J Curr Chem Pharm Sci 2012;2(4):226-32.

25. Antara S, Amla B. Chemical composition of methanolic extract of the leaves of Melia azedarach L. Asian J Pharm Clinical Res 2012;5(3):42-5.

26. Prabu MK, Sanydurai P, Subbaiyan B, Thangapandian V. Phytochemical constituentsand gas chromatography - Mass spectrometry analysis of Caralluma diffusa, (Wight) N.E.BR. Aerial part. Int J Pharm Pharm Sci 2013;5(3):602-5.

27. Blenkharn JI. The antimicrobial activity of taurolin - A possible additive for parenteral nutrition solutions. Clin Nutr 1987;6(1):35-8.

28. Sowmya S, Perumal PC, Gopalakrishnan VK. Chromatographic and spectrophotometric analysis of bioactive compounds from Cayratia trifolia (L.) stem. Int J Pharm Pharm Sci 2016;8(6):57-64.

29. Saradha M, Paulsamy S. GC-MS analysis for bioactive compounds from methanolic leaf and stem bark extracts of Hildegardia populifolia (Roxb.) Schott and Endl. Int J Pharm Sci Rev Res 2013;23(2):328-32. 